\title{
APLIKASI BAHAN SILIKA ALAMI DAN FREKUENSI PEMBERIAN NANO-SILIKA UNTUK MENINGKATKAN KUALITAS HASIL DAN USAHATANI PADI
}

\section{NATURAL SILICA APPLICATION AND NANO-SILICA FREQUENCY TO INCREASE YIELD AND RICE FARMING QUALITY}

\author{
Sulis Dyah Candra' ${ }^{1)}$, Ngatimun ${ }^{1)}$ dan Judi Suharsono ${ }^{1)}$ \\ ${ }^{1)}$ Fakultas Pertanian, Universitas Panca Marga \\ Email: sulis.d.candra@gmail.com
}

\begin{abstract}
ABSTRAK
Beberapa tahun terakhir, para peneliti pertanian menunjukkan minat yang meningkat dalam penggunaan silikon ( $\mathrm{Si}$ ) dalam tanaman untuk yang meningkatkan ketersediaan hara $(\mathrm{N}, \mathrm{P}, \mathrm{K})$, peningkatkan kinerja pertumbuhan dan efisiensi respons hasil, serta peningkatan toleransi terhadap tekanan biotik dan abiotik, serta toksisitas tanah $\mathrm{Al}, \mathrm{Fe}, \mathrm{Mn}$ dan garam yang berlebihan, tetapi perlu lebih banyak bukti pendukung tentang peran Si pada tanaman padi di lapang. Oleh karena itu, penelitian ini bertujuan untuk menyelidiki dampak pemberian silika alami maupun nano-Silika untuk meningkatkan kualitas hasil dan usahatani tanaman padi.

Metodologi penelitian yang dilakukan adalah Rancangan Petak Terbagi Faktorial yang diulang tiga kali dengan menggunakan uji lanjut BNT 5\%. Petak utama adalah Silika Alami dengan taraf: $\mathrm{A}_{0}$ (kontrol), $\mathrm{A}_{1}$ (Silika Sekam), $\mathrm{A}_{2}$ (Silika Arang Sekam), dan $\mathrm{A}_{3}$ (Silika Powder). Anak petak adalah perlakuan Nano Silikon (N) terdiri dari 4 taraf yaitu: $\mathrm{N}_{1}$ (frekuensi pemberian 1x), $\mathrm{N}_{2}$ (frekuensi pemberian $2 \mathrm{x}$ ), $\mathrm{N}_{3}$ (frekuensi pemberian $3 \mathrm{x}$ ), dan $\mathrm{N}_{4}$ (frekuensi pemberian $4 \mathrm{x}$ ).

Parameter pengamatan adalah: tinggi tanaman, jumlah daun per rumpun, jumlah anakan per rumpun, tingkat serangan hama utama, jumlah malai per rumpun, jumlah biji per malai, bobot gabah isi per malai, berat gabah kering giling dan hasil gabah per hektar. Sementara itu, dilakukan pula analisis usahatani yang mencakup biaya produksi tanaman padi dengan menggunakan teknologi aplikasi Si. Hasil pengamatan parameter pertumbuhan dan hasil pada tanaman secara umum menunjukkan perbedaan tidak nyata, namun pada pengaruh tunggal frekuensi pemberian $3 \mathrm{x}$ memberikan hasil yang terbaik. Sementara pada hasil usahatani menunjukkan bahwa pada pelaksanaan pertanian padi yang menggunakan silika memberikan keuntungan yang lebih besar dibandingkan metode konvensional.
\end{abstract}

Kata kunci: ketahanan tanaman; nano-silika; padi; silika alami; usahatani

\begin{abstract}
Silicon application in most plants tend to show increase induced resistance, growth and productivity. However, more field experiment evidence needed to support $\mathrm{Si}$ as a beneficial nutrients in plants. Therefore, this study aims to investigate experimentally the effects of giving silica both natural and nano-Silica to improve the quality and yield of rice farming.

The research methodology used was to use factorial split plot design which was repeated three times using a 5\% LSD test. As the main plot is natural silica
\end{abstract}


with levels: A0 (control), A1 (husk silica), A2 (charcoal silica), and A3 (silica powder). As subplots, nano silicon $(\mathrm{N})$ treatment consists of 4 levels, namely: N1 ( $1 \mathrm{x}$ frequency), $\mathrm{N} 2$ ( $2 \mathrm{x}$ frequency), N3 ( $3 \mathrm{x}$ frequency), and $\mathrm{N} 4$ (4x frequency).

Observation parameters in this study were: plant height, number of leaves per clump, number of tillers per clump, main pest attack rate, number of panicles per clump, number of seeds per panicle, weight of filled grain per panicle, weight of dried grain milled and grain yield per hectare. Meanwhile, an analysis of farming is also carried out which covers the cost of producing rice using this technology. The results of observations of growth parameters and yields on plants in general show no significant differences, but on the influence of a single frequency of $3 x$ gives the best results. While the results of farming shows that the implementation of rice farming using silica will provide greater benefits compared to conventional methods.

Keywords: farming; plant resistance; nano-silica; natural silica; rice

\section{PENDAHULUAN}

Upaya peningkatan produksi terutama padi di Indonesia sangat diperlukan dalam meningkatkan ketahanan pangan, mendukung program kemandirian pangan, pencapaian swasembada pangan, dan untuk mengantisipasi peningkatan permintaan beras akibat bonus demografi. Dinas Pertanian saat ini menjadikan pemantauan produksi padi sebagai prioritas utama dalam program kerjanya, sementara sesuai dengan RIRN 2017-2045, teknologi material nano silika merupakan salah satu target pada integrasi fokus riset bidang Pertanian (Pangan).

Data BPS (2018) selama kurun waktu tahun 2003 hingga tahun 2015, menunjukkan bahwa luas lahan sawah di Indonesia mengalami peningkatan yang cukup tinggi tetapi selama beberapa tahun terakhir cenderung menurun luasnya. Hal ini mengindikasikan semakin berkurangnya luasan lahan dan menurunnya potensi ekstensifikasi, sehingga di masa mendatang bidang pertanian harus fokus pada upaya intensifikasi pertanian.

Kondisi lahan sebagai media tanam merupakan salah satu kondisi pembatas utama dalam pertumbuhan dan hasil tanaman. Untuk dapat mencapai kapasitas produksi tanaman sesuai dengan potensi maksimal varietas, maka diperlukan kondisi media tanam yang optimal. Tanaman padi yang dibudidayakan di lahan marginal perlu mendapatkan nutrisi yang seimbang agar dapat tumbuh dengan optimal. Petani 
tradisional biasanya hanya berfokus pada pemberian pupuk dasar NPK saja untuk tanaman, sementara asupan hara mikro seperti unsur Silikon tidak pernah dilaksanakan atau kurang dipahami manfaatnya bagi tanaman.

Tanaman yang mengalami kecukupan unsur hara baik makro dan mikro akan memiliki ketahan dan tingkat produksi yang lebih baik serta menunjukkan toleransi yang baik terhadap serangan OPT. Penambahan silikat (Si) sangat diperlukan untuk mendukung peningkatan produksi padi nasional, di mana saat ini semakin mendesak dilaksanakan intensifikasi pertanian yang meliputi penggunaann lahan suboptimal, lahan endemik hama dan penyakit, maupun pertanian dengan menggunakan $\mathrm{N}$ dosis tinggi (Makarim, 2007).

Menurut Widowati (2011), untuk menjaga ketahanan pangan perlu didukung teknologi yang mampu meningkatkan efisiensi penggunaan pupuk, ramah lingkungan, dan mampu meningkatkan nilai produksi pangan. Terdapat beberapa teknologi yang mempunyai potensi untuk dikembangkan diantaranya produk input pertanian berteknologi nano.

Luyckx dkk. (2017), menyatakan bahwa unsur hara Silikon (Si), adalah unsur paling melimpah kedua setelah oksigen di bagian kerak bumi yang sebagian besar tersusun dari silikat. Selanjutnya Sahebi dkk. (2015) menyatakan bahwa dalam setiap kilogram tanah biasanya mengandung $\mathrm{Si}$ dengan kisaran antara 50-400 gram, dan paling banyak dijumpai dalam bentuk $\mathrm{SiO}_{2}$, namun solubilitas dan secara biogeokimiawinya immobile sehingga tidak banyak tersedia bagi tanaman. Sedangkan Menurut Meena dkk (2014), meskipun terdapat cukup melimpah dalam tanah, namun $\mathrm{Si}$ sebagian besar tidak tersedia bagi tanaman dan hilang akibat proses desilikasi. Silikon dalam tanah terus hilang karena proses tercuci/ leaching. Sangatlah penting untuk menjaga kadar $\mathrm{Si}$ pada tanaman sesuai dengan kebutuhannya agar tidak menghambat potensi pertumbuhan tanaman dan mencegah penurunan atau stagnasi produksi. Sementara Bhavya (2011), menyatakan bahwa hara Silikon dalam tanaman mampu mendukung 
dalam menghadapi kondisi tekanan biotik dan abiotik, selain pula dapat membantu mempertahankan kesetimbangan kadar air, aktivitas fotosintetik dan ketegaran daun.

Silikon dapat meningkatkan ketersediaan hara $(\mathrm{N}, \mathrm{P}, \mathrm{K})$, peningkatkan kinerja pertumbuhan dan efisiensi respons hasil, serta peningkatan toleransi terhadap tekanan biotik dan tekanan abiotik, serta toksisitas tanah $\mathrm{Al}, \mathrm{Fe}, \mathrm{Mn}$ dan garam yang berlebihan.Titik kritis $\mathrm{Si}$ di tanah adalah $40 \mathrm{mg} \cdot \mathrm{kg}^{-1}$ dan pada tanaman padi adalah 5\% dari berat total daun dan jeraminya (Rao dan Susmitha, 2017).

Liang (2006) menyatakan
bahwa $\mathrm{Si}$ antara lain dapat
menstimulasi pertumbuhan dan
perkembangan dari beberapa spesies
tanaman pangan. Silikon diketahui
dapat membantu tanaman lebih
toleran terhadap stress abiotik akibat
toksisitas, salinitas, dan kekeringan.

Parveen (2012), selanjutnya menyatakan bahwa aplikasi $\mathrm{Si}$ melalui perakarannya dapat meredakan efek drastis dari cekaman salin dengan mendukung keberlangsungan proses fotosintesis, melindungi dari stres oksidatif akibat garam, mengurangi radikal bebas yang mengganggu ketahanan tanaman.

Hal ini dikuatkan oleh Spann dan Schumann (2013) yang menyatakan bahwa aplikasi unsur hara silikon dapat mengurangi kemampuan memakan dari hama penghisap yang juga merupakan vektor patogen viral, sehingga dapat mengurangi resiko infeksi virus pada tanaman. Secara umum, menurut Singh (2015), keberadaan unsur Silikon bagi tanaman adalah menciptakan pembatas fisik dalam kutikula daun dan membantu meningkatkan ketahanan tanaman terhadap serangan hama dan penyakit.

Menurut Ma (2004), tanaman padi mampu mengakumulasi $\mathrm{Si}$ hingga $10 \%$ berat kering tanamannya. Kandungan 7\% Si dapat menekan kehilangan air hingga 20\% pada saat padi berada pada tahap masak susu dan pematangan bulir. Silikon juga dapat mengurangi rerata transpirasi hingga 30\% pada tanaman padi.

Penelitian ini diharapkan dapat mengetahui peran nano-silikon jika dikombinasikan dengan aplikasi silikon berbahan baku lokal guna meningkatkan kuantitas dan kualitas 
fase pertumbuhan dan hasil tanaman padi pada satu musim tanam. Penelitian ini menitikberatkan pengaruh pupuk $\mathrm{Si}$ berteknologi nano pada pertumbuhan tanaman padi dan perpaduannya dengan aplikasi silika alami (biosilika) dari bahan jerami dan sekam padi.

\section{METODE}

Metodologi penelitian yang digunakan adalah Rancangan Petak Terbagi Faktorial yang diulang tiga kali dengan menggunakan uji lanjut BNT 5\%. Petak utama adalah silika alami dengan taraf: $\mathrm{A}_{0}$ (kontrol), $\mathrm{A}_{1}$ (silika jerami $300 \mathrm{~kg} / \mathrm{Ha}$ ), $\mathrm{A}_{2}$ (silika sekam 300kg/Ha), $\mathrm{A}_{3}$ (silika arang jerami $300 \mathrm{~kg} / \mathrm{Ha}$ ), $\mathrm{A}_{4}$ (silika powder antara 70 kg/Ha). Sebagai Anak petaknya adalah perlakuan nano silikon (N) dengan konsentrasi 25 ppm, yang terdiri dari 4 taraf yaitu: $\mathrm{N}_{1}$ (frekuensi pemberian $1 \mathrm{x}$ ), $\mathrm{N}_{2}$ (frekuensi pemberian 2x), $\quad \mathrm{N}_{3}$ (frekuensi pemberian $3 \mathrm{x}$ ) , $\mathrm{N}_{4}$ (frekuensi pemberian 4x). Pemberian perlakuan nano silika dilakukan setelah tanaman berumur 60 HST dan diberikan dengan interval 7 hari sekali sesuai dengan perlakuan.

Parameter pengamatan adalah: tinggi tanaman, jumlah daun per rumpun, jumlah anakan per rumpun, tingkat serangan hama utama (penggerek batang dan wereng), jumlah malai per rumpun, jumlah biji per malai, bobot gabah isi per malai, berat gabah kering giling dan hasil gabah per hektar. Sementara untuk mengetahui aspek sosial ekonomi pertaniannya, dilakukan analisis usahatani yang mencakup biaya produksi tanaman padi dengan menggunakan teknologi nano silikon. 


\section{HASIL DAN PEMBAHASAN}

Tabel 1. Hasil Pengamatan Faktor Tunggal Frekuensi Nano Silika terhadap Beberapa Parameter Pengamatan

\begin{tabular}{cccccccccccc}
\hline \multirow{2}{*}{ Perlakuan } & \multicolumn{4}{c}{ Tinggi Tanaman } & \multicolumn{4}{c}{ Intensitas Serangan } & Jumlah & Berat \\
\cline { 2 - 9 } & 1 & 2 & 3 & 4 & 1 & 2 & 3 & 4 & Malai & Basah \\
\hline $\mathrm{A}_{1}$ & 44,01 & 55,82 & 65,59 & 73,64 & 14,76 & 17,07 & $17,23 \mathrm{a}$ & 24,04 & 29,21 & 53,67 \\
$\mathrm{~A}_{2}$ & 45,42 & 55,47 & 66,95 & 74,45 & 13,80 & 15,00 & $18,51 \mathrm{a}$ & 24,60 & 32,16 & 69,22 \\
$\mathrm{~A}_{3}$ & 44,62 & 55,19 & 64,50 & 72,76 & 11,71 & 12,05 & $13,13 \mathrm{~b}$ & 24,40 & 28,39 & 64,42 \\
$\mathrm{~A}_{4}$ & 44,56 & 54,95 & 63,35 & 72,11 & 14,06 & 14,21 & $15,18 \mathrm{ab}$ & 23,86 & 31,09 & 50,00 \\
$\mathrm{~N}_{1}$ & 44,58 & 55,75 & 64,80 & 70,38 & 15,52 & 17,13 & $17,43 \mathrm{c}$ & 23,24 & 30,01 & 49,08 \\
$\mathrm{~N}_{2}$ & 44,97 & 55,75 & 65,21 & 74,26 & 14,80 & 16,99 & $17,92 \mathrm{c}$ & 25,96 & 29,57 & 67,67 \\
$\mathrm{~N}_{3}$ & 44,97 & 55,24 & 65,91 & 74,16 & 13,18 & 15,02 & $12,77 \mathrm{a}$ & 23,01 & 32,22 & 68,50 \\
$\mathrm{~N}_{4}$ & 43,98 & 54,75 & 63,73 & 74,05 & 14,59 & 14,82 & $14,90 \mathrm{~b}$ & 24,03 & 30,26 & 46,08 \\
\hline
\end{tabular}

\section{Parameter Vegetatif}

Pada pengamatan pertumbuhan yaitu Parameter tinggi tanaman, jumlah daun dan jumlah malai maupun intensitas serangan pada aplikasi pemberian silika alami dan frekuensi nano-silikon, berdasarkan analisa varians tidak menunjukkan pengaruh nyata maupun pengaruh interaksi antar faktor. Terlepas dari beberapa hambatan kondisi lapang, perbedaan nyata hanya muncul di pengamatan parameter intensitas serangan pada pengamatan ke-3.

Pada parameter intensitas serangan pada tanaman padi menunjukkan perbedaan nyata, di mana pada pengamatan ke-3 pada perlakuan frekuensi nano Silika 3x $\left(\mathrm{N}_{3}\right) \quad$ menunjukkan intensitas serangan terkecil dibandingkan perlakuan lain, sementara pada $\mathrm{N}_{4}$ meskipun intensitasnya rendah namun tidak berbeda nyata dengan perlakuan $\mathrm{N}_{1}$ dan $\mathrm{N}_{2}$. Namun secara umum pemberian nano silika cukup efektif karena serangan OPT pada lahan petani dapat berkisar hingga lebih dari $30 \%$ yang dapat mengurangi hasil panen padi secara signifikan. Snyder (2006), menyatakan bahwa pemenuhan kebutuhan tanaman terhadap hara $\mathrm{Si}$, akan meningkatkan sistem perlindungan alami tanaman terhadap serangan penyakit, serangga dan kondisi cuaca yang kurang menguntungkan.

\section{Parameter Generatif}

Pada parameter generatif, yaitu pengamatan parameter berat basah tanaman (panen) pada aplikasi silika juga tidak menunjukkan pengaruh 
nyata maupun interaksi antar perlakuan.

Pada hasil pengamatan analisa petak terbagi terhadap beberapa parameter tanaman tidak menunjukkan perbedaan nyata maupun interaksi. Penyebabnya antara lain diduga karena tidak ada tanaman lain sejenis pada radius lebih dari $1 \mathrm{~km}$ di wilayah tersebut, sehingga serangan hama terkonsentrasi di lahan percobaan, terutama dari jenis hama burung pipit, belalang, walang sangit; sementara konsentrasi awal pengendalian ketahanan adalah terhadap serangan penyakit blast (Pyricularia oryzae Cav.) yang ternyata penyebab utamanya adalah diabaikannya sanitasi lahan berupa gulma oleh sebagian besar petani di wilayah tersebut. Sehingga berikutnya disarankan bagi petani dalam penanganan pengendalian serangan stem blast tersebut, dilakukan pengendalian terpadu yang berkesinambungan antara budidaya yang dengan pengendalian OPT yang lebih ramah lingkungan. Salah satunya adalah dengan penggunaan silika yang dapat mengurangi penggunaan pestisida dan meningkatkan keuntungan usahatani tanaman padi.

Dari beberapa hambatan di lapang tersebut, peneliti belum mampu memberi bukti pendukung bagi pernyataan Husnain dkk. (2012), yang menyatakan bahwa sebagian besar lahan memiliki kandungan $\mathrm{Si}$ tersedia tanah yang rendah, sementara dengan pemberian nano-silika $160 \mathrm{~kg}$ hingga $200 \mathrm{~kg}$ ha1 dapat meningkatkan hasil padi secara nyata; dimana pemberian nano-silika dapat pula disetarakan dengan aplikasi kompos jerami dan abu sekam pada lahan sawah. Selanjutnya Yohana dkk. (2013), menyatakan bahwa aplikasi nanosilika dapat memberi pengaruh yang nyata dalam meningkatkan $\mathrm{pH}$ tanah, serapan Si tanaman, jumlah anakan maksimum dan bobot kering gabah. Dari hasil riset yang lain, yang dilakukan oleh Ningsari (2017), pemberian silikon dari bahan abu sekam pada tanaman padi berpengaruh secara signifikan pada tinggi tanaman, sudut daun, jumlah anakan produktif. Serta pernyataan menurut Sabatini dkk. (2017), bahwa dengan perlakuan nano silikon memberikan peningkatan pada 
parameter tinggi tanaman dan jumlah anakan padi. Perlakuan nano silikon $10 \mathrm{ml} . \mathrm{L}^{-1}$ memberikan pengaruh yang terbaik, sementara pola pertumbuhan tinggi tanaman cenderung meningkat hingga umur 40 Hari Setelah Tanam.

\section{Analisa Usahatani Penanaman Padi dengan Aplikasi Silika}

Tabel 2. Rata-rata penggunaan input usahatani padi sistem silika dan konvensional per ha

\begin{tabular}{|c|c|c|c|c|c|c|c|}
\hline \multirow[t]{2}{*}{ No } & \multirow{2}{*}{ Komponen input } & \multicolumn{3}{|c|}{ Pertanian Silika } & \multicolumn{3}{|c|}{ Petani Konvensional } \\
\hline & & Volume & Harga (Rp) & Nilai (Rp) & Volume & Harga (Rp) & Nilai (Rp) \\
\hline $\mathrm{I}$ & BIAYA & & & & & & \\
\hline 1 & Bibit & 25 & 9.000 & 225.000 & 25 & 9.000 & 225.000 \\
\hline \multirow[t]{6}{*}{2} & Pupuk & & & & & & \\
\hline & Urea $(\mathrm{kg})$ & 290 & 1.900 & 550.487 & 290 & 1.900 & 550.487 \\
\hline & SP $36(\mathrm{~kg})$ & 50 & 2.100 & 104.307 & 50 & 2.100 & 104.307 \\
\hline & Phonska (kg) & 227 & 2.350 & 533.027 & 227 & 2.350 & 533.027 \\
\hline & $\mathrm{ZA}$ & 66 & 1.450 & 96.019 & 66 & 1.450 & 96.019 \\
\hline & Kompos & 199 & 800 & 158.944 & & & \\
\hline 3 & Pestisida & 4 & 125.000 & 500.000 & 16 & 125.000 & 2.000 .000 \\
\hline 4 & Silika organic & 7 & 68.000 & 476.000 & & & \\
\hline \multirow[t]{10}{*}{5} & TKLK & & & & & & \\
\hline & Mengolah lahan & 2 & 80.000 & 160.000 & 2 & 80.000 & 160.000 \\
\hline & Mencacah tanah & 4 & 80.000 & 320.000 & 4 & 80.000 & 320.000 \\
\hline & Menanam & 8 & 80.000 & 640.000 & 8 & 80.000 & 640.000 \\
\hline & Memupuk & 4 & 80.000 & 320.000 & 4 & 80.000 & 320.000 \\
\hline & Mencabut gulma & 4 & 80.000 & 320.000 & 4 & 80.000 & 320.000 \\
\hline & Mengendalikan OPT & 2 & 80.000 & 160.000 & 16 & 80.000 & 1.280 .000 \\
\hline & Aplikasi Si & 6 & 80.000 & 480.000 & & & \\
\hline & Panen & 10 & 80.000 & 800.000 & 10 & 80.000 & 800.000 \\
\hline & Mengeringkan gabah & 2 & 80.000 & 160.000 & 2 & 80.000 & 160.000 \\
\hline \multirow[t]{6}{*}{6} & Peralatan & & & & & & \\
\hline & Hand Sprayer & 1 & 650.000 & 650.000 & 1 & 650.000 & 650.000 \\
\hline & Sewa Traktor & 1 & 350.000 & 350.000 & 1 & 350.000 & 350.000 \\
\hline & Penyusutan & 1 & 58.500 & 58.500 & 1 & 58.500 & 58.500 \\
\hline & Pajak & 1 & 477.778 & 477.778 & 1 & 589.884 & 589.884 \\
\hline & Total Biaya & & & 7.540 .062 & & & 9.157 .224 \\
\hline \multirow[t]{2}{*}{ II } & PENDAPATAN & & & & & & \\
\hline & Hasil Panen & 2.676 & 6.500 & 17.394.000 & 2.676 & 6.500 & 17.394.000 \\
\hline \multirow[t]{5}{*}{ III } & KEUNTUNGAN & & 9.853 .938 & & & 8.236 .776 & \\
\hline & BEP Volume Produksi & & $1.160,01$ & & & $1.408,80$ & \\
\hline & BEP Harga Produksi & & $2.817,66$ & & & $3.421,98$ & \\
\hline & B/C Ratio & & 2,31 & & & 1,90 & \\
\hline & ROI & & $130,69 \%$ & & & $111,17 \%$ & \\
\hline
\end{tabular}

Dari Tabel 2 dapat diketahui bahwa nilai keuntungan kotor dari usahatani silika adalah sebesar sekitar Rp 9.853.900 sementara pada pertanian konvensional sebesar Rp 8.236.800. Selanjutnya untuk menentukan kelayakan pelaksanaan usahatani padi dengan aplikasi silika, maka dilakukan penghitungan ekonomi: 


\section{Analisa Biaya Produksi BEP Volume Produksi}

BEP Volume Produksi $=\frac{\text { Total biaya produksi }}{\text { Harga di tingkat petani }}$

Hasil

perhitungan

menunjukkan bahwa pada saat diperoleh produksi padi yang mampu dicapai sebanyak $1.160,01$ $\mathrm{kg}$ pada sistem silika, atau $1.408,80$ kg pada sistem konvensional, maka usahatani padi tersebut pada kondisi impas, yaitu tidak menghasilkan untung tetapi juga merugi.

\section{Analisa Biaya Produksi BEP Harga Produksi}

BEP Harga Produksi $=\frac{\text { Total Biaya Produksi }}{\text { Total Produksi }}$ Hal ini menunjukkan bahwa pada saat harga padi di tingkat petani yang mencapai Rp 2.817,66 pada sistem silika, atau Rp 3.421,98 pada sistem konvensional, maka usaha tani padi tersebut tidak mengalami keuntungan, tetapi tidak pula mengalami kerugian.

\section{B/C Ratio}

$B /$ C Ratio $=\frac{\text { Total Pendapatan }}{\text { Total Biaya Produksi }}$

Nilai $\mathrm{B} / \mathrm{C}$ ratio sebesar 2,31 pada sistem silika, atau 1,90 pada sistem konvensional menunjukkan bahwa dari pengeluaran biaya sebesar Rp. 7.540.062 akan diperoleh penerimaan 2,31 kali dari biaya yang dikeluarkan pada sistem silika, dan dari pengeluaran biaya sebesar Rp. 9.157.224 akan diperoleh penerimaan 1,90 kali dari biaya yang dikeluarkan pada sistem konvensional.

\section{Return of Investment}

ROI $=\frac{\text { Keuntungan Usahatani }}{\text { Modal Usahatani }} \times 100 \%$

Nilai ROI sebesar 130,69\% pada sistem silika dan $111,17 \%$ pada sistem konvensional menunjukkan bahwa pada setiap pengeluaran modal usahatani sebesar Rp 100 maka akan diperoleh keuntungan sebesar sebesar Rp 13.069 pada sistem silika dan Rp 11.117 pada sistem konvensional.

\section{KESIMPULAN DAN SARAN}

\section{Kesimpulan}

Frekuensi pemberian nano silika 3x memberikan hasil serangan terendah $(12,77 \%)$, Berdasarkan analisa usahatani, maka pemberian silika akan lebih menguntungkan $(\mathrm{B} / \mathrm{C}$ ratio $=2,31)$. 
Saran

Disarankan untuk melakukan aplikasi silika pada uji komparasi multi lokasi dan multi musim tanam untuk mengetahui hasil yang lebih komprehensif.

\section{UCAPAN TERIMA KASIH}

Ucapan terima kasih

disampaikan kepada Direktorat

Penelitian dan Pengabdian Kepada

Masyarakat Dirjen Pendidikan

Tinggi Kementrian Riset dan

Teknologi, yang telah memberikan

hibah sesuai dengan Surat Keputusan

Nomor: 7/E/KPT/2019 19 Februari

2019, Kontrak Nomor:

113/SP2H/LT/DRPM/2019 11 Maret

2019; 30/SP2H/LT/MONO/L7/201

26 Maret 2019; dan

069.10/SP2H/LPPM/MONO/2019

28 Maret 2019.

\section{DAFTAR PUSTAKA}

Badan Pusat Statistik. 2018. Luas Lahan Sawah Menurut Provinsi (ha), 2003-2015 https://www.bps.go.id/dynamic table/2015/09/10/895/luas-

lahan-sawah-menurut-provinsiha-2003-2015.html updated on Feb 2018. Diakses pada 3 Agustus 2018.

Bhavya, H.K., V. Nache Gowda, S. Jaganath, K.N. Sreenivas, N.B.
Prakash. 2011. Effect of Foliar Silicic Acid and Boron Acid in Bangalore Blue Grapes. Proceedings of The 5th International Conference on Silicon in Agriculture. September 13-18, 2011. Beijing, China.

He, Congwu. Jie Ma dan Lijun Wang. 2015. A hemicellulose-bound form of silicon with potential to improve the mechanical properties and regeneration of the cell wall of rice. New Phytologist. 206 (3): 10511062.

https://doi.org/10.1111/nph.13 282.

Husnain, S. Rochayati, dan I. Adamy. 2012. Pengelolaan Hara Silika pada Tanah Pertanian di Indonesia. Prosiding Seminar Nasional Teknologi Pemupukan dan Pemulihan Lahan Terdegradasi. Badan Litbang Pertanian di Balai Penelitian Tanah, Bogor. P 237-246.

Husnain, S. Rochayati, dan I. Adamy. 2012. Pengelolaan Hara Silika pada Tanah Pertanian di Indonesia. Prosiding Seminar Nasional Teknologi Pemupukan dan Pemulihan Lahan Terdegradasi. Badan Litbang Pertanian di Balai Penelitian Tanah, Bogor. P 237-246.

Kementrian Pertanian. 2015. Rencana Strategis Kementrian Pertanian Tahun 2015-2019. Jakarta. Diunduh dari: http://www1.pertanian.go.id/fil 
e/RENSTRA_2015-2019.pdf

Diakses pada 3 Agustus 2018.

Liang, Yongchao, W. Sun, Y. Zhu \& P. Christie. 2006. Mechanisms of silicon-mediated alleviation of abiotic stresses in higher plants: A review. Environmental Pollution. 1-7.

Ma, Jian Feng. 2004. Role of silicon in enhancing the resistance of plants to biotic and abiotic stresses, Soil Science and Plant Nutrition. 50(1): 11-18, DOI: 10.1080/00380768.2004.10408 447

Makarim, A.K., E. Suhartatik dan A. Kartohardjono. 2007. Silikon, Hara Penting Tanaman Padi. Iptek Tanaman Pangan. 2 (2): 195-204. Balai Besar Penelitian Tanaman Padi.

Meena, V. D., M. L. Dotaniya, Vassanda Coumar, S. Rajendiran, Ajay, S. Kundu, A. Subba Rao. 2014. A Case for Silicon Fertilization to Improve Crop Yields in Tropical Soils. Proc. Natl. Acad. Sci., India, Sect. B Biol. Sci. 84(3): 505518.

Ningsari, O. 2017. Frekuensi Aplikasi dan Konsentrasi Ekstrak Abu Sekam Berpelarut Asap Cair sebagai Pupuk Silikon terhadap Pertumbuhan Tanaman Padi. Fakultas Pertanian Universtas Jember. $59 \mathrm{P}$.

Parveen, N.. 2012. Influence of Silicon on Growth and Some Physiological Attributes of Maize (Zea mays L.) Under Salt Stress. Doctor of
Phylosophy in Botany Thesis. University of Agriculture, Faisalabad.

Rao, G.B. dan P. Susmitha. 2017. Silicon management in Rice. International Journal of Chemical Studies 2017. 5(6): 1359-1361. India

Sabatini, S.D., R. Budihastuti, S.W.A. Suedy. 2017. Pengaruh Pemberian Pupuk Nanosilika terhadap Tinggi Tanaman dan Jumlah Anakan Padi Beras Merah. Buletin Anatomi dan Fisiologi Undip. 2 (2).

Sahebi, M., M. M. Hanafi, S. N. Akmar, A. Rafii, M. Y., A. P. Tengoua, N. M. Azwa, dan J. Shabanimofrad, M. 2015. Importance of silicon and mechanisms of biosilica formation in plants. BioMed Research International $10.1155 / 2015 / 396010$ 23146141

Singh, D.P. 2015. Plant Nutrition in the Management of Plant Diseases with Particular Reference to Wheat. Springer India. DOI 10.1007/978-81322-2571-3_20

Snyder, G. H., V. V. Matichenkov, L. E. Datnoff. 2006. Handbook of Plant Nutrition (Books in Soils, Plants, and the Environment). pp 551-562.

Widowati, L.R., Husnain, dan W. Hartatik. 2011. Peluang Formulasi Pupuk Berteknologi Nano. Badan Litbang Pertanian di Balai Penelitian Tanah. Bogor. 307-316. 
Wyttenbach A., V. Furrer, P. Schleppi, and L. Tobler. 1998.

Rare earth elements in soil and in soil-grown plants. Plant Soil. 199, 267-273.

Yohana, O., H. Hanum, dan Supriadi. 2013. Pemberian Bahan Silika pada Tanah Sawah Berkadar P Total Tinggi untuk Memperbaiki Ketersediaan P dan Si Tanah, Pertumbuhan dan Produksi Padi. Jurnal Agroekoteknologi 1 (4) . 